\title{
PERSEPSI GURU BAHASA INDONESIA TENTANG HUBUNGAN ANTARA PENERAPAN FULL DAY SCHOOL DAN PENGUATAN KARAKTER SISWA
}

\author{
Imam Safi'i, Silih Warni, dan Prima Gusti Yanti \\ Universitas Muhammadiyah Prof. DR. HAMKA Jakarta \\ Email: imamsafii2077@uhamka.ac.id
}

\begin{abstract}
Abstrak: Penelitian ini bertujuan untuk mendeskripsikan persepsi para guru bahasa Indonesia SMA di Wilayah Provinsi DKI Jakarta, Indonesia tentang hubungan antara penerapan full day school dan penguatan pendidikan karakter bagi siswa. Data penelitian ini diperoleh melalaui survei secara online kepada sejumlah guru bahasa Indonesia. Sampel yang digunakan dalam penelitian adalah bersifat purposive sehingga tidak dapat dijadikan sebagai landasan untuk menggeneralkan persepsi dari sejumlah populasi. Data yang dideskripsikan dalam penelitian ini mencakup dua hal, yaitu berupa hubungan antara status kepegawaian dan pengalaman kerja dengan persepsi tentang full day school sebagai penguatan pendidikan karakter bagi siswa. Hasil penelitian menunjukan, bahwa terdapat hubungan status kepegawaian dan pengalaman dengan persepsi terhadap sistem full day school sebagai penguatan pendidikan karakter siswa, yaitu (1) hubungan antara pengalaman dan persepsi terhadap full day school sebagai wahana penguatan karakter siswa sebesar 0.161; dan (2) hubungan antara status kepegawaian dan persepsi terhadap full day school sebagai wahana penguatan pendidikan karakter siswa sebesar 0.033. Hasil Penelitian ini dapat dimanfaatkan sebagai salah satu evaluasi mengenai efektivitas penerapan full day school dalam sistem persekolahan di Indonesia.
\end{abstract}

Kata kunci: persepsi, pengalaman, status kepegawaian, full day school

\section{PERCEPTION OF INDONESIAN LANGUAGE TEACHERS ABOUT RELATIONSHIP BETWEEN APPLICATION OF FULL DAY SCHOOL AND STRENGTHENING STUDENT CHARACTERS}

\begin{abstract}
This study aims to describe the perceptions of senior high school Indonesian language teachers in the DKI Jakarta Province, Indonesia about the relationship between implementing full day school and strengthening character education of student. The research data was obtained through an online survey of a number of Indonesian Language Teachers. The sample used in the study is purposive so that it cannot be used as a basis for generalizing the perception of a number of populations. The data described in this study includes two things, namely in the form of a relationship between staffing status and work experience with perceptions about full day school as a reinforcement of character education of student. The results show that there is a relationship between staffing status and experience with the perception of the full day school system as a reinforcement of student character education, namely (1) the relationship between experience with the perception of full day school as a vehicle for strengthening the character of students is equal to 0.161; and (2) the relationship between employment status with the perception of full day school vehicle for strengthening student character education is 0.033 . The results of this study can be used as an evaluation of the effectiveness of implementing Full Day School in the school system in Indonesia.
\end{abstract}

Keywords: Perception, experience, employment status, full day school

\section{PENDAHULUAN}

Tahun 2016 lalu Menteri Pendidikan dan Kebudayaan Republik Indonesia, Muhadjir Effendy, mencanangkan sebuah kebijakan yang sempat mengundang pro dan kontra, yaitu kebijakan full day school (sekolah sehari penuh). Kebijakan tersebut ditujukan untuk mendukung perwujudan pendidikan yang ideal, yaitu terpenuhinya pengetahuan umum dan terbangunnya karakter (Kompas.com, 8 Januari 2018). Pendidikan karakter merupakan salah satu upaya untuk menjawab berbagai tantangan kemanusiaan yang ditimbulkan oleh perkembangan teknologi yang begitu masif. Perkembangan teknologi yang sangat cepat 
memicu timbulnya berbagai problem kemanusiaan yang semakin hari bukan semakin berkurang, tetapi semakin bertambah. Berbagai kasus terkait dengan melemahnya karakter bangsa terjadi di mana-mana dan terjadi di berbagai kalangan mulai dari kalangan masyarakat pada umumnya hingga kalangan elite.

Beberapa penelitian yang berkaitan dengan penerapan full day school menunjukkan bahwa terdapathasil yang lebih baik antara sistem pembelajaran full day school dibandingkan dengan half day school (sekolah setengah hari). Secara keseluruhan, anakanakyang belajar di taman kanak-kanak sepanjang hari atau full day menunjukkan peningkatan prestasi akademik yang lebih besar daripada anak-anak yang belajar setengah hari. Hasil kuesioner yang diberikan kepada guru dan orang tua juga menunjukkan tingkat kepuasan yang tinggi terhadap taman kanak-kanak yang menerapkan pembelajaran dengan sistem full day school (Baskett, Bryant, White, \& Rhoads, 2005).

Beaver pada tahun 2006 juga melakukan penelitian serupa, yaitu menguji hubungan antara kehadiran siswa di full day school dan half day school. Hasil penelitian menunjukkan bahwa di tengah-tengah siswa kelas satu yang menyelesaikan satu tahun pra sekolah penuh hari secara signifikan mengungguli siswa yang tidak menghadiri pra sekolah dengan sistem setengah hari (Valenti \& Tracey, 2009). Dina (2011) sebagaimana dikutipoleh (Astuti, 2013), dalam penelitiannya yang berjudul Pengaruh Full Day School Terhadap Kecerdasan Sosial Anak Kelas IV di SDIT Bina Anak Sholeh Yogyakarta, juga menemukan fakta bahwa pendidikan atau sekolah dengan sistem full day school kian diminati. Alasannya adalah karena waktu belajar di sekolah lebih panjang. Konsepini dianggap mampu mengembangkan kreativitas dan keilmuan anak didik se- cara lebih tepat, sehingga hal tersebut dapat meningkatkan kecerdasan sosial anak.

Berkenaan dengan beberapa fakta mengenai efektivitas dari sistem full day school tesebut, maka pantaslah jika Ontario Ministry of Education (2011) mengatakan bahwa pembelajaran sehari penuh adalah bagian dari rencana pendidikan untuk membantu lebih banyak anak mendapatkan awal yang kuat di sekolah sehingga mereka dapat terus sukses, hidup yang bermanfaat. Menurutnya, dengan memberi mereka lebih banyak kesempatan di usia muda, berarti mereka juga memberi masa depan yang cerah bagi anak-anak kami. Hal tersebut juga dipertegas oleh bahwa konsep ini dianggap mampu mengembangkan kreativitas dan keilmuan anak didik secara lebih tepat, sehingga hal tersebut dapat meningkatkan kecerdasan sosial anak. Holm (2014) juga mengutarakan berdasarkan hasil penelitiannya bahwa membangun sekolah-sekolah sehari penuh di Vollsmose menciptakan suatu yang pasti dinamis di sekolah-sekolah dan masyarakat lokal sekitarnya.

Full day school menurut MOET (2009) dianggap sebagai model yang baik untuk menciptakan kualitas sekolah dasar hingga pendidikantinggi karena full day school adalah kegiatan pembelajaran dengan memanfaatkan waktu lebih atau melangsungkan pembelajaran selama satu hari penuh (Liễu, 2014). Syukur (Soapatty, 2014) menekankan, bahwa sistem pembelajaran Full Day School selain pengembangan kreativitas juga terdapat 3 ranah belajar, yaitu kognitif, afektif, dan psikomotorik. Demikian halnya dengan pendapat Hasan (2006) sebagaimana dikutip oleh Kristiawan (2017), yang menegaskan bahwa pembelajaran dengan sistem sehari penuh juga mampu mengembangkan soft skill yang eksploratif seperti mencari, bertanya, menyelidiki, memformat pertanyaan, mencari jawaban 
dan menangkap dengan tepat fenomena alam sebagai bahan untuk menghubungkan diri.

Berdasarkan bebeberapa pendapat mengenai full day school yang telah dipaparkan di atas dapat disimpulkan bahwa sistem full day school merupakan sistem pembelajaran sehari penuh yang digunakan sebagai media untuk meningkatkan efektivitas pembelajaran. Melalui sistem full day school kesempatan belajar siswa akan lebih banyak. Dengan demikian, berbagai potensi siswa, baik berkenaan dengan kognitif, afektif, maupun psikomotor dapat dikembangkan secara lebih komprehensif. Dengan model full day school yang memberi kesempatan banyak kepada siswa untuk melakukan pembelajaran dan berinteraksi sosial di sekolah juga dapat mengurangi dampak buruk yang diakibatkan oleh banyaknya interaksi sosial di luar sekolah, apalagi jika siswa tersebut tidak mampu mengelola waktu luangnya di luar sekolah.

Lalu pertanyaannya adalah bagaimana relevansi antara penyelenggaraan sistem full day school dan penguatan pendidikan karakter? Pendidikan telah dianggap sebagai pusat keunggulan dalam mempersiapkan karakter manusia yang luar biasa. Keyakinan ini mendorong setiap orang untuk siap menghadapi tantangan global (Rokhman, Syaifudin, \& Yuliati, 2014). Full day school sebagai sistem pendidikan yang melangsungkan kegiatan pembelajaran sehari penuh dapat dijadikan sebagai wahana yang sangat efektif untuk melangsungkan pendidikan karakter. Minat dan harapan siswa pada peningkatan kemampuan karakter mereka cukup tinggi. Setelah pelajaran, peserta didik meningkatkan kemampuan karakter untuk menangani masalah dalam berbagai situasi (Kim, 2015). Peserta didik diberikan kesempatan yang seluasluasnya untuk mengembangkan karakter- nya dengan mengikuti berbagai aktivitas yang diprogramkan sekolah, baik di dalam kelas maupun di luar kelas. Hal ini akan lebih efektif ketika sekolah mampu merancang program-program yang baik yang memfasilitasi peserta didik untuk mengembangkan sikap dan perilakunya dengan baik.

Goleman (Pane \& Patriana, 2016) menegaskan bahwa pendidikan karakter pada dasarnya adalah pendidikan nilai-nilai yang melibatkan aspek pengetahuan (kognitif), perasaan, dan tindakan. Karakter adalah aspek dari kepribadian. Karakter guru sangat penting dalam pencapaian tujuan pendidikan di samping pengetahuan lapangannya, pengetahuan umumnya, dan pengetahuan pedagogisnya (Ülger, Yiğittir, \& Ercan, 2014).

Berbagai upaya dalam bermoral dan pendidikan karakter telah diteliti dan diperbincangkan pada dekade pertama abad 21 di banyak bagian dunia termasuk Asia, Amerika Utara, dan Eropa (e.g. Althof \& Berkowitz, 2006; Cheng, 2004; Ferrari, 2006; Lee \& Ho, 2005; Rowe, 2006; Lee, Pan, Liao, Chen, \& Walters, 2013). Salah satu contoh penelitian tentang pendidikan karakter adalah penelitian di Taiwan yang berjudul "Budaya Sekolah Berbasis Karakter Proyek" (CBSC), yang diluncurkan pada tahun 2004. Proyek ini sangat berbeda dari program pendidikan moral atau karakter tradisional, yang berfokus pada kurikulum formal dengan tujuan pasif membentuk siswa yang patuh dan santun selain mengurangi mereka perilaku yang merugikan (Lee, et al., 2013). Di Amerika Serikat organisasi profesional juga mengisyaratkan para pendidik untuk membuat kurikulum yang tidak hanya mengembangkan keterampilan profesional, tetapi juga memupuk karakter (e.g. AICPA, 2008; Davis \& McLaughlin, 2009; Fontaine, 2012; Huber \& Mafi, 2013). Contoh, American Institute of Certified Public Accoun- 
tants (AICPA) menekankan bahwa kompetensi pribadi termasuk pengembangan soft skill dalam perilaku pribadi, pengambilan keputusan, interaksi, dan kemampuan berkomunikasi. Individu yang memasuki profesi akuntansi harus bersikap dengan cara yang konsisten dengan karakter dan standar disiplin akuntansi. Kompetensi pribadi tersebut berkaitan dengan melibatkan dan menunjukkan objektivitas, integritas, dan perilaku etis (Huber \& Mafi, 2013).

Feszterova \& Jomova juga mengadakan penelitian berkaitan dengan pendidikan karakter yang diintegrasikan dengan pendidikan lingkungan. Melalui kegiatan tersebut para siswa memiliki banyak peluang untuk bekerja sama dalam persiapan penelitian dan juga di daerah penelitian. Mereka dapat berpartisipasi dalam implementasi hasil menjadi kerja nyata. Dengan bantuan rangsangan dan elemen motivasi yang berbeda, guru dan siswa dapat menciptakan situasi pendidikan yang memotivasi tindakan, serta pendidikan di lingkungan (Feszterova \& Jomova, 2015). Kemudian Bogomaz, et al. (2015) juga melakukan penelitian serupa, yaitu dengan memfokuskan pada kekuatan karakter sebagai sumber daya pribadi yang positif untuk pengembangan pribadi dan profesional generasi muda dari perspektif psikologi positif.

Berdasarkan paparan mengenai full day school dan pendidikan karakter di atas dapat ketahui bahwa sistem full day school, yaitu dengan pemanfaatan waktu yang lebih lama dalam melangsungkan pendidikan di sekolah dapat dijadikan sebagai media yang efektif untuk penguatan pendidikan karakter siswa. Namun demikian, wacana penerapan full day school masih menjadi polemik di kalangan masyarakat. Oleh karena itu, penelitian ini secara spesifik akan mendeskripsikan tentang bagaimana persepsi para guru bahasa Indonesia di wilayah Provinsi DKI Jakarta Indonesia mengenai hubungan antara full day school dan penguatan pendidikan karakter siswa.

\section{METODE}

Penelitian ini menggunakan pendekatan kuantitatif dengan metode survei, yaitu suatu metode yang digunakan untuk meneliti gejala suatu keolompok atau perikau individu, (Sarwono, 2006). Sampel yang digunakan berupa sampel purposif, yaitu para guru bahasa Indonesia di Sekolah Menengah Atas yang berada di Provinsi DKI Jakarta.

Data penelitian ini dikumpulkan melalui survei secara online dengan menggunakan instrumen angket yang berbentuk media googleform yang didistribusikan kepada sejumlah responden melalui media WhatsApp. Hal ini mengacu pada pendapat Zhang dkk. bahwa beberapa studi survei komputer menghasilkan hasil yang sama seperti kertas dan survei pensil, misalnya, pada kuesioner sikap (Zhang, et al., 2017). Data yang telah dikumpulkan dari instrumen tersebut tidak dimaksudkan sebagai sampel untuk mewakili sejumlah populasi. Data tersebut hanya digunakan untuk melihat secara riil mengenai respons dari sejumlah responden yang telah ditetapakan sebelumnya.

Data yang terkumpul kemudian dianalisis secara kuantitatif. Analisis yang digunakan berupa analisis korelasi product moment model Pearson, yaitu teknik analisis dengan mengorelasikan antara data variabel dependen dengan data variabel idependen guna mengukur tingkat hubungan antarvairabel tersebut. Data yang diuji tingkat signifikansi hubungan antarvariabel tersebut mengenai hubungan antara status kepegawaian dan pengalaman dengan persepsi tentang full day school sebagai penguatan pendidikan karakter. 


\section{HASIL DAN PEMBAHASAN}

Penelitian ini adalah penelitian survei yang bertujuan untuk mendeskripsikan persepsi para guru bahasa Indonesia di SMA yang berada di wilayah Provinsi DKI Jakarta tentang hubungan antara penerapan full day school dan penguatan pendidikan karakter. Ada beberapa hal penting yang perlu dikemukakan dan dibahas terkait dengan tujuan tersebut. Secara rinci hasil penelitian dan pembahasannya disajikan di bawah ini.

Hubungan antara Status Kepegawaian dan Persepsi Mengenai Full Day School Sebagai Penguatan Pendidikan Karakter Siswa

Ada tiga hal penting yang perlu dikemukakan terkait dengan hasil penelitian tentang hubungan antara status kepegawaian dan persepsi mengenai full day school sebagai penguatan pendidikan karakter siswa di SMA di DKI Jakarta, yaitu persamaan regresi, koefisien korelasi berganda, dan koofesien determinasi. Ketiga hal ini disajikan seperti berikut.

\section{Persamaan Regresi}

Tabel 1. Regresi antara Status Kepegawaian dengan Persepsi terhadapfull day school

\begin{tabular}{|c|c|c|c|c|c|}
\hline \multirow{2}{*}{ Model } & \multicolumn{2}{|c|}{$\begin{array}{c}\text { Unstandardized } \\
\text { Coefficients }\end{array}$} & \multirow{2}{*}{$\begin{array}{l}\text { Standardized } \\
\text { Coefficients }\end{array}$} & \multirow{2}{*}{$\mathrm{t}$} & \multirow{2}{*}{ Sig. } \\
\hline & B & Std. Error & & & \\
\hline (Constant) & 49.638 & 7.305 & & 6.795 & .000 \\
\hline Profile responden & 7.014 & 5.380 & .232 & 1.304 & .202 \\
\hline
\end{tabular}

Status didefinisikan sebagai gengsi, rasa hormat, dan kekaguman individu menikmati di mata orang lain (Lount \& Pettit, 2012). Berdasarkan tabel di atas dapat diketahui bahwa nilai konstanta untuk kolom Unstandardized Coefficients B adalah sebesar 49.638 dan nilai tentang profil responden atau status kepegawaian adalah sebesar 7.014. Jadi, dapat diketahui jika persamaan regresi adalah $\mathrm{Y}=49.638+7.014$. Persamaan regresi tersebut menunjukkan adanya kontribusi positif dari kuat atau lemahnya hubungan antara profil responden atau status kepegawaian dan persepsi terhadapfull day school sebagai penguatan pendidikan karakter. Setiap peningkatan profil responden atau status kepegawaian akan meningkatkan tingkat persepsi terhadap full day school sebagai penguatan pendidikan karakter.

Hubungan antara status kepegawaian seseorang dengan persepsi terhadap suatu hal ini relevan dengan pernyataan, bahwa status pekerjaan dianggap sebagai hasil fungsional yang sangat penting dari individu (Fujino, et al., 2016). Pendapat Fujino dkk. tersebut mengindikasikan bahwa status pekerjaan atau kepegawaian akan menjadi citra bagi induvidu. Semakin tinggi status pekerjaan individu, maka semakin naik pula citra dan persepsi terhadap suatu hal. Hal ini sejalan dengan literatur ekonomi yang ada menunjukkan bahwa status sosial individu secara signifikan memengaruhi kesejahteraan subjektif dan berkorelasi dengan perilaku dalam berbagai domain (Bucciol, Cavasso, \& Zarri, 2015).

\section{Koefisien Korelasi Berganda}

Tabel 2. Model Summary

\begin{tabular}{ccccc}
\hline Model & $\mathrm{R}$ & $\begin{array}{c}\mathrm{R} \\
\text { Square }\end{array}$ & $\begin{array}{c}\text { Adjusted } \\
\text { R Square }\end{array}$ & $\begin{array}{c}\text { Std. Error } \\
\text { of the } \\
\text { Estimate }\end{array}$ \\
\hline 1 & $.232^{\mathrm{a}}$ & .054 & .022 & 13.684 \\
\hline
\end{tabular}


Berdasarkan hasil output SPSS tabel model summary pada nilai " $\mathrm{R}$ " adalah sebesar 0. 232. Nilai tersebut menunjukkan bahwa derajat kekuatan hubungan antara variabel independen (profil responden atau status kepegawaian) dan variabel dependen (persepsi terhadap full day school sebagai penguatan pendidikan karakter) berada pada derajat hubungan rendah (0,20-0,399). Hubungan tersebut tentu bukan tanpa alasan. Berdasarkan beberpa kajian, terlihat bahwa di samping status sosial, ekonomi, dan beberapa aspek yang berada di sekitar individu akan memengaruhi sikap dan persepsi individu terhadap suatu hal. Oleh karena itu, tidak berlebihan jika pernyataan tersebut juga dianalogikan dengan pendapat Ornstein (1989) yang mengatakan bahwa setiap jenis tata letak kantor, fitur tata letak kantor, seperti tingkat privasi juga dapat bervariasi, dan menentukan pengaruhnya pada budaya tempat kerja adalah minat. Tata letak kantor merupakan elemen lingkungan fisik yang dapat bertindak sebagai representasi simbolis yang dapat mempengaruhi sikap karyawan dan perilaku (Zerella, von Treuer, \& Albrecht, 2017).

\section{Koefisien determinasi}

Nilai koefisien determinasi yang terdapat pada tabel model summary pada kolom "R Square" adalah sebesar 0.054. Berdasarkan nilai tersebut dapat diketahui bahwa kontribusi atau keefektifan dari variabel dependen (profil responden atau status kepegawaian) terhadap variabel dependen (persepsi terhadap full day school sebagai penguatan pendidikan karakter) adalah sebesar 0,54\%. Meskipun tidak signifikan, status kepegawaian seseorang akan berhubungan dan berpengaruh terhadap persepsinya mengenai suatu hal. Di samping itu, konteks sosial juga tidak jarang akan memengaruhi pandangan seseorang terhadap suatu hal, sebagaimana pendapat Lount \& Pettit bahwa beberapa orang telah mempertimbangkan bagaimana kepercayaan dipengaruhi oleh konteks sosial terjadinya interaksi. Lebih lanjut dikatakan bahwa hubungan antara status dan kepercayaan dapat bergantung pada kontekstual lainnya. Misalnya, dalam situasi persaingan yang ketat atara kinerja atau kemampuan seseorang, anggota berstatus lebih tinggi dapat merasakan tingkat kenyamanan yang lebih tinggi daripada orang lain yang statusnya lebih rendah (Lount \& Pettit, 2012).

\section{Hubungan Antara Masa Kerja dan Persep- si Mengenai Full Day School Sebagai Pe- nguatan Pendidikan Karakter Siswa}

Seperti halnya hubungan antara status kepegawaian dan persepsi mengenai full day school sebagai penguatan pendidikan karakter siswa, pada hubungan antara masa kerja dan persepsi mengenai full day school juga akan disajikan dalam tiga hal, yaitu persamaan regresi, koefisien korelasi berganda, dan koofesien determinasi. Ketiga hal ini disajikan seperti berikut.

\section{Persamaan Regresi}

Tabel 3. Persamaan Regresi

\begin{tabular}{|c|c|c|c|c|c|}
\hline \multirow{2}{*}{ Model } & \multicolumn{2}{|c|}{$\begin{array}{c}\text { Unstandardized } \\
\text { Coefficients }\end{array}$} & \multirow{2}{*}{$\begin{array}{c}\text { Standardized } \\
\text { Coefficients }\end{array}$} & \multirow{2}{*}{$t$} & \multirow{2}{*}{ Sig. } \\
\hline & $\mathrm{B}$ & Std. Error & & & \\
\hline (Constant) & 1.404 & .398 & & 3.527 & .001 \\
\hline $\begin{array}{c}\text { Profile } \\
\text { responden }\end{array}$ & .006 & .007. & .161 & .891 & .380 \\
\hline
\end{tabular}


Berdasarkan output SPSS dapat diketahui, bahwa nilai konstanta untuk kolom Unstandardized Coefficients B adalah sebesar 1.404 dan nilai tentang masa kerja adalah sebesar 0.006. Jadi, dapat diketahui jika persamaan regresi adalah $\mathrm{Y}=1.404+0.006$. Persamaan regresi tersebut menunjukkan adanya kontribusi positif dari kuat atau lemahnya hubungan antara masa kerja dan persepsi terhadap full day school sebagai penguatan pendidikan karakter. Setiap peningkatan masa kerja atau pengalaman akan meningkatkan tingkat persepsi terhadap full day school sebagai penguatan pendidikan karakter. Setidaknya hal ini mengacu pada analogi yang mengaitkan antara persepsi dengan sikap seseorang yang di- nukil dalam bidang olahraga, yaitu bahwa persepsi dari pengalaman olahraga di masa remaja akan ikut menentukan partisipasi lanjutan sebagai seorang anak yang pada gilirannya terbukti memiliki pengaruh terhadap tingkat aktivitas fisik di masa dewasa (Miller \& Siegel, 2017). Artinya, pengalaman seseorang akan memberikan kontribusi dalam membangun persepsi seseorang terhadap sesuatu, dalam hal ini adalah pengalaman seorang guru yang memiliki hubungan dengan persepsi terhadap full day school. Aksi dan persepsi membentuk lingkaran atau siklus yang mencirikan interaksi lingkungan organisme (Määttänen, 2017).

\section{Koefisien Korelasi Berganda}

Tabel 4. Koefisien Korelasi Berganda

\begin{tabular}{lcccc}
\hline Model & R & Adjusted R & \multicolumn{2}{c}{$\begin{array}{c}\text { Std. Error of the } \\
\text { Square }\end{array}$} \\
\hline 1 & $.161^{\mathrm{a}}$ & .026 & -.007 & Estimate \\
\hline
\end{tabular}

Berdasarkan hasil output SPSS tabel model summary pada nilai " $\mathrm{R}$ " adalah sebesar 0.161. Nilai tersebut menunjukkan bahwa derajat kekuatan hubungan antara variabel independen (masa kerja atau pengalaman) dan variabel dependen (persepsi terhadap full day school sebagai penguatan pendidikan karakter) berada pada derajat hubungan sangat rendah $(0,00-0,199)$. Meskipun pada kisaran yang sangat rendah, persepsi guru terhadap full day school sebagai penguatan pendidikan karakter tersebut tentu dipengaruhi oleh pengalaman yang dimilkinya, baik yang berupa pengalaman akademis karena kualifikasi pendidikan merupakan atribut penting dari individu guru (Ho, Lee, \& Teng, 2016), maupun pengalaman nonakademis, yaitu berupa jaringan sosial. Jaringan sosial guru sangat penting untuk menempa dan mem- pertahankan pembelajaran, pengembangan, dan komitmen guru (Ho, Lee, \& Teng, 2016).

\section{Koefisien determinasi}

Nilai koefisien determinasi yang terdapat pada tabel model summary pada kolom "R Square" adalah sebesar 0.026. Berdasarkan nilai tersebut dapat diketahui bahwa kontribusi atau keefektifan dari variabel dependen (masa kerja) terhadap variabel dependen (persepsi terhadap full day school sebagai penguatan pendidikan karakter) adalah sebesar $0,26 \%$. Pengalaman, yaitu berupa masa kerja individu, akan memengaruhi persepsi tentang suatu hal meskipun tidak selalu signifikan. Hal tersebut dapat dianalogikan dengan pendapat A.D. Miller, Ramirez, \& Murdock, 2017, bahwa pandangan para guru tentang motivasi siswa akan memengaruhi harapan yang mere- 
ka miliki untuk siswa mereka dan mempengaruhi interaksi guru dengan siswa. Di samping itu, kemandirian, yang dimaknai dengan pengalaman, guru berdampak pada tipe lingkungan belajar seorang guru memberikan yang mempengaruhi siswa prestasi (Miller, Ramirez, \& Murdock, 2017).

\section{PENUTUP}

Hasil penelitian ini menunjukkan bahwa terdapat hubungan status kepegawaian dan pengalaman dengan persepsi terhadap full dayschool sebagai upaya penguatan pendidikan karakter siswa. Meskipun tidak terlalu signifikan tipa-tiap variabel dependen (status kepegawaian dan pengalaman) memengaruhi variabel independen (full day school sebagai penguatan pendidikan karakter). Hal tersebut menunjukkan bahwa status kepegawaian dan pengalaman seseorang akan membangun persepsi seseorang terhadap suatu hal.

Sampel yang digunakan dalam penelitian ini bersifat purposive. Oleh karena itu, hasil penelitian ini tidak dapat digunakan untuk menarik simpulan secara umum. Dengan kata lain, persepsi dari sejumlah responden dalam penelitian ini tidak dapat mewakili populasi. Meskipun demikian, hasil penelitian tetap dapat digunakan sebagai informasi awal untuk mengetahui persepsi dari sejumlah guru mengenai wacana penerapan full day school dalam skala nasional yang telah diutarakan oleh Mendikbud, Muhadjir Effendy, pada tahun 2016 yang lalu serta menimbulkan polemik yang berkepanjangan antarbeberapa kalangan masyarakat.

\section{UCAPAN TERIMA KASIH}

Ucapan terima kasih yang mendalam kami sampaikan kepada Prof. Suswandari, M.Pd. selaku Ketua Lembaga Penelitian Universitas Muhammadiyah Prof. DR. HAMKA beserta seluruh tim yang telah memberikan berbagai fasilatas sehingga penelitian ini dapat terselesaikan. Kami juga mengucapkan terima kasih kepada seluruh Bapak/Ibu Guru Bahasa Indonesia di Wilayah Provinsi DKI Jakarta yang telah berkenan mengisi angket guna melengkapi data penelitian ini. Penulis mengucapkan terima kasih yang sebesarbesarnya kepada Ketua Dewan Redaksi Jurnal Pendidikan Karakter yang telah menerima artikel ini kemudian melakukan editing hingga akhirnya dimuat dalam penerbitan edisi ini.

\section{DAFTAR PUSTAKA}

Astuti, M. (2013). Implementasi program fullday school sebagai usaha mendorong perkembangan sosial peserta didik TK Unggulan Al- Ya'lu Kota Malang, Jurnal Kebijakan dan Pengembangan Pendidikan, 1(2),133-140. Retrieved from: http://ejournal.umm.ac.id/index.php/jmkpp/article/view/1561/1658.

Baskett, R., Bryant, K., White, W., \& Rhoads, K. (2005). Half-day to full-day kindergarten: An analysis of educational change scores and demonstration of an educational research collaboration. Early Child Development and Care, 175 (5), 419-430. DOI: https://doi.org/10.1080/0300443042000266259.

Bogomaz, S. A., Litvina, S. A., Kozlova, N. V., \& Atamanova, I. V. (2015). Culture-specific Subjective Evaluation of Character Strengths. Procedia - Social and Behavioral Sciences, 200, 92-100. DOI:https://doi.org/10.1016/j..2015.08 .024 .

Bucciol, A., Cavasso, B., \& Zarri, L. (2015). Social status and personality traits. Journal of Economic Psychology, 51, 245-260. DOI: https://doi.org/10.1016/j.joep.2015.10.002.

Feszterova, M., \& Jomova, K. (2015). Cha- 
racter of Innovations in Environmental Education. Procedia - Social and Behavioral Sciences, 197, 1697-1702. DOI: https:// doi.org/10.1016/j.sbspro.201 5.07.222

Fujino, H., Sumiyoshi, C., Sumiyoshi, T., Yasuda, Y., Yamamori, H., Ohi, K., ... Imura, O. (2016). Predicting employment status and subjective quality of life in patients with schizophrenia. Schizophrenia Research: Cognition, 3, 20-25. DOI: https://doi.org/10.1016/j.scog.2015.10.005.

Ho, D., Lee, M., \& Teng, Y. (2016). Exploring the relationship between schoollevel teacher qualifications and teachers' perceptions of school-based professional learning community practices. Teaching and Teacher Education, 54, 32-43. DOI: https://doi.org/10.1016/j.tate.2015.11.005.

Holm, L. (2014). Parental perspectives on Danish full-day schools for ethnic-minority students. International Journal about Parents in Education, 8(1), 26-33.

Huber, M.M., \& Mafi, S.L. (2013). Education par excellence: Developing personal competencies and character through philanthropy-based education. Journal of Accounting Education, 31(3), 310-332. DOI: https://doi.org/10.1016/j.jaccedu.2013.07.001.

Kim, D. (2015). A study on the class of education that builds students' character through films - classes at the university of liberal arts. Procedia - Social and Behavioral Sciences, 174, 1529-1533. DOI: https://doi.org/10.1016/j.sbspro.2015.01.784.

Kristiawan, M. (2017). The characteristics of the full day school based elementary school. Transylvanian Review Cluj-Napoca Transylvanian Review Transylvanian Review, 25(14), 12-14. Retrieved from: https://www.researchgate.net-
/publication/316087309_The_Characteristics_of_the_Full_Day_School_Based_Elementary_School.

Lee, C.Y., Pan, P.J. Der, Liao, C.J., Chen, H.Y., \& Walters, B. G. (2013). E-character education among digital natives: Focusing on character exemplars. Computers and Education, 67, 58-68. DOI: https://doi.org/10.1016/j.compedu.2013.02.020.

Liễu, T.T.B. (2014). Full Day Schooling Performance of Primary Schools in Disadvantaged Areas in Vietnam : A Comparative Case Study. 30(4), 1730. Retrieved from: http://repository.vnu.edu.vn/bitstream/VNU_123/57472/1/301-1-576-1-10-20160427.pdf.

Lount, R.B., \& Pettit, N.C. (2012). The social context of trust: The role of status. Organizational Behavior and Human Decision Processes, 117(1), 15-23. DOI: https://doi.org/10.1016/j.obhdp.2011.07.005.

Määttänen, P. (2017). Emotions, values, and aesthetic perception. New Ideas in Psychology, 47, 91-96. DOI: https://doi.org/10.1016/j.newideapsych.2017.03.009.

Miller, A.D., Ramirez, E.M., \& Murdock, T. B. (2017). The influence of teachers' self-efficacy on perceptions: Perceived teacher competence and respect and student effort and achievement. Teaching and Teacher Education, 64, 260-269. DOI: https://doi.org/10.1016/j.tate.2017.02.008.

Miller, S.M., \& Siegel, J.T. (2017). Youth sports and physical activity: The relationship between perceptions of childhood sport experience and adult exercise behavior. Psychology of Sport and Exercise, 33, 85-92. DOI: https://doi.org/10.1016/j.psychsport.2017.08.009. 
Ontario Ministry of Education. (2011). The full-day early learning - kindergarten program, 162. Retrieved from: http://www.edu.gov.on.ca/eng/curriculum/elementary/kindergarten.html.

Pane, M.M., \& Patriana, R. (2016). The significance of environmental contents in character education for quality of life. Procedia - Social and Behavioral Sciences, 222, 244-252. DOI: https://doi.org/10.1016/j.sbspro.2016.05.153

Rokhman, F., Hum, M., Syaifudin, A., \& Yuliati. (2014). Character education for golden generation 2045 (National character building for indonesian golden years). Procedia - Social and Behavioral Sciences, 141, 11611165. DOI: https://doi.org/10.1016/j.sbspro.2014.05.197.

Sarwono, J. (2006). Metode penelitian kuantitatif \& kualitatif, 306. Retrieved from https://www.academia.edu/9832986/Buku_Metodologi_Peneliti an_Kuantitatif_dan_Kualitatif_oleh _Jonathan_Sarwono.

Soapatty, L. (2014). Pengaruh sistem sekolah sehari penuh (full day school) terhadap prestasi akademik siswa SMP Jati Agung Sidoarjo. E-Journal UNESA, 2(2), 719-733. Retrieved from http://ejournal.unesa.ac.id/index.php/jurnal-pendidikan-kewarganegaraa/article/view/7860.
Ülger, M., Yiğittir, S., \& Ercan, O. (2014). Secondary school teachers' beliefs on character education competency. Procedia - Social and Behavioral Sciences, 131(4310), 442-449. DOI: https://doi.org/10.1016/j.sbspro.2014.04.145.

Valenti,J.E. \& Tracey, D.H. (2009). Full-day, half-day, and no preschool. Education and Urban Society, 41(6), 695-711. Retrieved from http://journals.ohiolink.edu/ejc/article.cgi?issn $=0013124$ 5 \&issue $=\mathrm{v} 41 \mathrm{i} 0006$ \&article=695_fhanp.

Zerella, S., von Treuer, K., \& Albrecht, S. L. (2017). The influence of office layout features on employee perception of organizational culture. Journal of Environmental Psychology, 54, 1-10. DOI: https://doi.org/10.1016/j.jenvp.2017. 08.004 .

Zhang, X.C., Kuchinke, L., Woud, M.L., Velten, J., \& Margraf, J. (2017). Survey method matters: Online/offline questionnaires and face-to-face or telephone interviews differ. Computers in Human Behavior, 71, 172-180. DOI: https://doi.org/10.1016/j.chb.2017.02.006. 